\title{
Investigating the Frequency of Stroke in SARS-CoV-2 Cases in Sakarya City, Turkey
}

\author{
Sakarya İli SARS-CoV-2 Olgularında İnme Sıklığının Araştırılması
}

\author{
Dilcan KOTAN ${ }^{1}$ \\ (iD) 0000-0002-8624-6321 \\ Onur TAYDAŞ ${ }^{2}$ \\ (D) 0000-0002-9881-7240 \\ Ömer Faruk ATEŞ² \\ (D) 0000-0002-0281-1128 \\ Mehmet Halil ÖZTÜRK ${ }^{4}$ \\ (D) 0000-0002-4530-7167
}

\begin{abstract}
Aim: The aim of this study is to identify the frequency of stroke among severe acute respiratory syndrome coronavirus 2 (SARS-CoV-2) cases in Sakarya city, to find out the clinical characteristics of patients diagnosed with stroke and to contribute to the national database.

Material and Methods: This retrospective study was carried out with 783 cases diagnosed with SARS-CoV-2 between April-June 2020 at the pandemic hospital in Sakarya city. Patients were compared in terms of age, National Institute of Health Stroke Scale (NIHSS), risk factors, radiological findings, inpatient treatment, intubation, and mortality rates.

Results: Out of 26 cases of ischemic stroke, 11 (42.3\%) were male and $15(57.7 \%)$ were female. In terms of infarction localization, the cause was medial cerebral artery (MCA) in 4 $(15.4 \%)$ patients, top of the basilar in $2(7.7 \%)$ patients, basilar artery in $1(3.8 \%)$ patient, lacunar in $9(34.6 \%)$ patients and anterior system in $10(38.5 \%)$ patients. There was no significant difference in terms of D-dimer and C-reactive protein (CRP) levels according to disease severity (both $\mathrm{p}=0.262$ ). Three $(0.38 \%)$ patients presented with stroke findings and were diagnosed with SARS-CoV-2. Cryptogenic stroke was detected in $8(30.8 \%)$ of the SARS-CoV-2 cases. Stroke frequency was calculated as $3.3 \%$ among the SARS-CoV-2 cases in Sakarya city.

Conclusion: This is the first study to identify the frequency of stroke among SARS-CoV-2 patients in Sakarya city and Turkey. Our study is important as it shows that preventing or treating ischemic stroke in SARS-CoV-2 cases contributes greatly to the reduction of mortality.
\end{abstract}

Keywords: Sakarya city; SARS-CoV-2; stroke; frequency.

\section{ÖZ}

Amaç: $\mathrm{Bu}$ çalışmanın amacı Sakarya ilindeki şiddetli akut solunum yolu sendromu koronavirüsü 2 (severe acute respiratory syndrome coronavirus 2, SARS-CoV-2) olgularında inme sıklığını tespit etmek, inme tanısı almış olan hastaların klinik özelliklerini ortaya koyabilmek ve ulusal veri tabanına katkıda bulunmaktır.

Gereç ve Yöntemler: Bu çalışma, Sakarya ilindeki pandemi hastanesinde Nisan-Haziran 2020 tarihleri arasında SARS-CoV-2 tanısı alan 783 olgu ile geriye dönük olarak yürütüldü. Hastalar, yaş, Ulusal Sağlık Enstitüleri İnme Skalası (National Institute of Health Stroke Scale, NIHSS), risk faktörleri, radyolojik bulgular, yatarak tedavi, entübe olma durumları ve mortalite oranları bakımından karşılaştırıldı.

Bulgular: Yirmi altı iskemik inmeli olgunun $11(\% 42,3)$ 'i erkek ve $15(\% 57,7)$ 'i kadın idi. Enfarkt lokalizasyonu bakımından 26 hastanın $4(\% 15,4)$ 'ü orta serebral arter (medial cerebral artery, MCA), $2(\% 7,7)$ 'si baziller tepe, $1(\% 3,8)$ 'i baziller arter, $9(\% 34,6)$ 'u laküner, 10 $(\% 38,5)$ 'u arka sistemden kaynaklanmaktaydı. D-Dimer ve C-reaktif protein (C-reactive protein, CRP) düzeyleri bakımından hastalık şiddetine göre anlamlı bir farklılık yoktu (her iki $\mathrm{p}=0,262)$. Üç $(\% 0,38)$ hasta inme bulgusuyla gelip SARS-CoV-2 tanısı almıştı. SARS-CoV-2 olgularının $8(\% 30,8)$ 'inde kriptojenik inme tespit edildi. Sakarya ilinde SARS-CoV-2 olgularında inme sıklığı \%3,3 olarak hesaplandı.

Sonuç: Bu çalışma SARS-CoV-2 hastalarında inme sıklığını tespit etmeye yönelik Sakarya ilinde ve Türkiye'de yapılmış ilk çalışmadır. Çalışmamız, SARS-CoV-2 olgularında iskemik inmenin önlenebilmesi ve tedavi edilebilmesinin mortalitenin azalmasına belirgin katk1 sunduğunu göstermesi bakımından önemlidir.

Accepted / Kabul Tarihi : 02.11.2020 Available Online /

Çevrimiçi Yayın Tarihi : 25.11.2020
Anahtar kelimeler: Sakarya ili; SARS-CoV-2; inme; sıklık. 


\section{INTRODUCTION}

Even though respiratory symptoms are usually focused on in severe acute respiratory syndrome coronavirus 2 (SARS-CoV-2) cases, we predicted that there may be accompanying neurological symptoms due to our familiarity with the coronavirus family. Stroke in SARS-CoV-2 cases is caused by changes in the body due to infection and or the presence of risk factors (1). The study that reported the first cases of stroke in Wuhan also noted that there were risk factors present in these cases. On the other hand, stroke was also reported in young cases without any risk factors. This appears to be evidence suggesting that both ways are possible (1-3). Some studies on SARS-CoV-2 reported that stroke was much more frequent in severe cases with pulmonary involvement (4-6). In cases of SARS-CoV-2, the most commonly reported condition in the literature has been ischemic stroke. Less often, hemorrhagic stroke and sinus vein thrombosis have been reported. In SARS-CoV-2 cases, young cases with stroke along with cases presented with only stroke reveal that stroke can also occur at the onset of the disease (6-8). The fact that thrombotic complications were identified in $31 \%$ of the cases despite systematic thrombosis prophylaxis shows the importance of evaluating patients in intensive care in terms of thromboembolism prophylaxis. One of the most important markers of this progression is thought to be the D-dimer level (9-11). Antithrombotic treatment such as low molecular weight heparin and aspirin has been recommended for SARS-CoV-2 patients with low D-dimer level $(11,12)$. Starting from March 11, 2020, the day when the first positive case was detected in Turkey, antithrombotic treatment has been a part of the routine procedure as per the treatment guidelines of the Ministry of Health (13). We think that the reason behind the low mortality rates in Turkey could be this prophylactic treatment. The objective of our study is to identify the frequency of stroke among SARS-CoV-2 cases in Sakarya city and to contribute to the national database and literature.

\section{MATERIAL AND METHODS}

In this study, 783 cases diagnosed with SARS-CoV-2 at the emergency department, wards and intensive care units between April 1 and June 15, 2020 at Sakarya Training and Research Hospital, which was declared a pandemic hospital in March, were retrospectively reviewed. The diagnosis was made by evaluating nasopharyngeal swaps with polymerase chain reaction (PCR) and thorax computed tomography (CT), which presented atypical viral pneumonia. The study was approved by the Ethics Committee of the Sakarya University Faculty of Medicine (27.07.2020, 437) and the General Directorate of Health Services of the Ministry of Health. SARS-CoV-2 cases over the age of 18 , who required neuroimaging due to stroke pre-diagnosis, were screened from the hospital registration system. Hemorrhagic stroke cases, cases with previous stroke history, and cases with missing data were excluded from the study. Demographic data, medical history, neurological examination result, electrocardiogram (ECG), brain CT, diffusion-weighted magnetic resonance imaging (MRI), PA chest radiograph, blood biochemistry, hemogram test, C-reactive protein (CRP), D-dimer and fibrinogen values of the cases, ischemic stroke diagnosis of which was confirmed by clinical and radiological sources, were recorded. Known or newly-identified accompanying chronic diseases such as cardiac failure, arrhythmia, myocardial infarction, diabetes, hypertension, chronic obstructive pulmonary disease, pulmonary hypertension, pulmonary embolism, and chronic renal failure were recorded. Stroke localization was performed by evaluating ischemic territories in the brain based on brain CT and diffusion-weighted MRI findings. Infarction areas were divided into three groups, namely anterior cerebral artery (ACA), posterior cerebral artery (PCA) and medial cerebral artery (MCA), taking into account arterial watershed areas. The National Institute of Health Stroke Scale (NIHSS) levels, which determine the severity of the disease based on neurological examination of patients, were recorded. Those with a NIHSS score of 1 to 8 were classified as mild, 9 to 15 as moderate, higher than 16 as severe.

\section{Statistical Analysis}

Statistical analysis was performed by using statistical package SPSS v.25.0. Continuous data are described by mean \pm standard deviation (SD) or median interquartile range (IQR) and (minimum-maximum), categorical data are presented as numbers and percentages. Shapiro-Wilk test was used to evaluate the normality assumption for numerical variables. In the evaluation of the data, a Student's t-test was used for the data with normal distribution in order to compare numerical variables, a Mann-Whitney U test was used for the data that were not normally distributed, and a Pearson Chi-square or Fisher's exact test was used in the analysis of categorical variables. Statistical significance was considered as 0.05 .

\section{RESULTS}

SARS-CoV-2 patients were showing clinical stroke findings and were diagnosed with ischemic stroke with neuroimaging. Out of 26 cases of ischemic stroke, 11 $(42.3 \%)$ were male and $15(57.7 \%)$ were female. The mean age of the patients was $71.7 \pm 12.3$, the mean age of the male patients was $72.0 \pm 10.8$ and the mean age of the female patients was $71.5 \pm 12.7$ years. Only $2(7.7 \%)$ of the patients were 45 years of age and under. Seventeen $(65.4 \%)$ of the patients had a medical history of hypertension, 9 (34.6\%) patients had diabetes and $3(11.5 \%)$ patients had cardiac disease. Nine $(34.6 \%)$ of the patients were smokers and 1 (3.8\%) patient consumed alcohol. There was no significant difference in terms of advanced age, and comorbidities according to the disease severity. Demographic characteristics and risk factors of patients are shown in Table 1.

In terms of the sub groups of infarction localization, the cause was MCA in $4(15.4 \%)$ patients, top of the basilar in $2(7.7 \%)$ patients, basilar artery in $1(3.8 \%)$ patient, lacunar in $9(34.6 \%)$ patients and anterior system in $10(38.5 \%)$ patients. In terms of the anatomical localization of lesions of ischemic stroke patients, $4(15.4 \%)$ patients had partial anterior CI, $13(50.0 \%)$ had posterior CI, 9 (34.6\%) had lacunar while no patients had total anterior CI.

Patients were compared in terms of their NIHSS score, which was calculated using the NIHSS during admission to the clinic, risk factors, radiological localization findings, 
duration of stay at hospital, duration of intubation, and mortality rates. In terms of risk factors of the patient group, the relationship between age/sex and glucose level at arrival, HbA1C, diabetes, hypertension, heart disease, smoking and alcohol use was not statistically significant. Patients requiring intensive care were grouped under severe cases and those followed-up in wards were grouped under non-severe cases. Sixteen $(61.5 \%)$ cases were followed-up in intensive care, $10(38.5 \%)$ cases were intubated and $8(30.8 \%)$ cases died. CRP and D-dimer levels of 26 patients that were included in the study did not show a significant difference between severe and nonsevere cases (both $\mathrm{p}=0.262$ ). There only was a significant difference in NIHSS according to the disease severity between severe and non-severe cases $(\mathrm{p}<0.001$, Table 2$)$. Three $(0.38 \%)$ patients presented with stroke findings and were diagnosed with SARS-CoV-2. Cryptogenic stroke was detected in $8(30.8 \%)$ of the SARS-CoV-2 cases. Stroke frequency was calculated as $3.3 \%$ among the SARS-CoV-2 cases in Sakarya city.

Table 1. Clinical characteristics of patients with SARS-CoV-2

\begin{tabular}{|c|c|c|c|c|}
\hline & Total $(n=26)$ & Severe $(n=16)$ & Non-severe $(n=10)$ & $\mathbf{p}$ \\
\hline Age (years), mean \pm SD & $71.7 \pm 12.3$ & $71.6 \pm 14.0$ & $71.4 \pm 12.7$ & 0.971 \\
\hline \multicolumn{5}{|l|}{ Age, n (\%) } \\
\hline$<45$ & $2(7.7)$ & $1(6.3)$ & $1(10.0)$ & \multirow{2}{*}{0.730} \\
\hline$\geq 45$ & $24(92.3)$ & $15(93.8)$ & $9(90.0)$ & \\
\hline \multicolumn{5}{|l|}{$\operatorname{Sex}, \mathrm{n}(\%)$} \\
\hline Male & $11(42.3)$ & $8(50.0)$ & $3(30.0)$ & \multirow{2}{*}{0.428} \\
\hline Female & $15(57.7)$ & $8(50.0)$ & $7(70.0)$ & \\
\hline Comorbidities (any), n (\%) & $8(28.6)$ & $3(16.7)$ & $5(50.0)$ & 0.091 \\
\hline Hypertension, $\mathrm{n}(\%)$ & $17(65.4)$ & $8(50.0)$ & $9(90.0)$ & 0.087 \\
\hline Diabetes mellitus, n (\%) & $9(34.6)$ & $4(25.0)$ & $5(50.0)$ & 0.234 \\
\hline Cardiac disease, $\mathrm{n}(\%)$ & $3(11.5)$ & $2(12.5)$ & $1(10.0)$ & 0.846 \\
\hline Smoke, n (\%) & $9(34.6)$ & $3(18.8)$ & $6(60.0)$ & 0.046 \\
\hline Alcohol, n (\%) & $1(3.8)$ & $0(0.0)$ & $1(10.0)$ & 0.385 \\
\hline
\end{tabular}

SARS-CoV-2: severe acute respiratory syndrome coronavirus 2, SD: standard deviation

Table 2. Laboratory findings of patients with SARS-CoV-2

\begin{tabular}{lcccc}
\hline & Total $(\mathbf{n = 2 6})$ & Severe $(\mathbf{n}=\mathbf{1 6})$ & Non-severe $(\mathbf{n = 1 0})$ & $\mathbf{p}$ \\
\hline C-reactive protein $(\mathbf{m g} / \mathbf{L})$ & $23.3(64.2)[1.1-288]$ & $33.2(59.8)[1.1-288]$ & $7.6(45.4)[3-231]$ & 0.262 \\
D-dimer (mg/L) & $1505(2247)[331-29400]$ & $1660(3652)[373-29400]$ & $1450(1879)[331-3220]$ & 0.262 \\
NIHSS & $23(20)[5-39]$ & $27(12)[23-39]$ & $9(6)[5-16]$ & $<\mathbf{0 . 0 0 1}$ \\
Imaging Pattern, n (\%) & $9(34.6)$ & & & \\
$\quad$ Lacunar & $17(65.4)$ & $4(25.0)$ & $5(50.0)$ & 0.234 \\
$\quad$ Other & $12(75.0)$ & $5(50.0)$ & \\
SARS-CoV-2: severe acute respiratory syndrome coronavirus 2, NIHSS: national institutes of health stroke scale, data were presented as median (interquartile range) [minimum-maximum]
\end{tabular}

\section{DISCUSSION}

First, from Zhongnan Hospital in Wuhan, China, where the pandemic first emerged, then, from around the world, as of February 7, 2020, neurologists have started to report common neurological symptoms including stroke $(6,14-16)$. It has been reported that blood coagulation tests (prothrombin and D-dimer) of SARS-CoV-2 patients showed abnormal results, which increased the possibility of ischemic stroke. Initial publications reported stroke in 5\% of the cases $(4,17)$. Among 388 patients, who applied to a university hospital in Italy, $2.5 \%$ had ischemic stroke and the mean age of these patients was $68.4 \pm 5.9$ years (18). A study involving over 2000 SARS-CoV-2 patients found that the rate of cerebrovascular presentations was higher in severe cases (19). In our study, we investigated 783 SARS-CoV-2 positive patients at a pandemic hospital in Sakarya city and ischemic stroke was detected in 26 of these cases. Stroke frequency was calculated as 3.3\% among the SARS-CoV2 cases in Sakarya city.
Literature reports that in stroke cases, hypertension, diabetes and cardiovascular diseases increase the severity of disease $(6,14,17,20)$. Especially in cases where risk factors for stroke are present such as hypertension, diabetes and smoking, SARS-CoV-2 is much more frequent and severe. In our study, only $8(30.8 \%)$ cases developed stroke without having any risk factor. In cryptogenic cases, transthoracic echocardiogram and Doppler ultrasonography of the carotid vertebral artery could not be performed due to pandemic restrictions, which led to a limitation in determining stroke etiology. The age range of SARS-CoV-2 patients with ischemic stroke has varied in studies. In a most comprehensive study carried out on more than 26 thousand SARS-CoV-2 cases in 99 centers, the mean age of ischemic stroke was 71 (6). In our study, the age range was in line with the literature. Only $2(7.7 \%)$ cases were below the age of 45 .

Subtyping, which is the next step after a stroke diagnosis, is 
of vital importance in predicting prognosis, determining discharge and treatment strategies and preventing recurrence. In literature, large vascular occlusion has been reported in the majority of the cases $(6,21)$. Only $6(23.1 \%)$ of our stroke patients had large vascular occlusion. $3(11.5 \%)$ cases arrived at the hospital presenting with stroke. Out of these, 2 cases actually started having fever and fatigue symptoms a few days back but refrained from going to the hospital because of the pandemic. Another case applied to another hospital presenting with weakness of the left side. Upon suspicion at the ER, this case was tested and was referred to the pandemic hospital after being diagnosed with SARS-CoV-2.

Literature reports that stroke can also occur at the onset of SARS-CoV-2 in cases who only present with stroke manifestations without showing any other symptoms such as fever, cough and loss of appetite (19). Only one case in our study presented with stroke at the onset of SARS-CoV-2.

SARS-CoV-2 can enter the brain via retrograde neuronal or hematogenous propagation $(9,17)$. Due to its direct damage on the nervous system and inflammation, hypoxia, immobilization and disseminated intravascular coagulation it causes, this virus is thought to make people susceptible to venous and arterial thromboembolic events. Due to the known fact that the disease makes people susceptible to thromboembolic events, prophylactic antithrombotic treatment is recommended for patients with high D-Dimer levels (13,22-24). Twenty three $(88.5 \%)$ of our cases were receiving prophylactic subcutaneous heparin and acetylsalicylic acid treatment at two equal doses before the diagnosis. CRP and D-dimer levels of our stroke cases significantly decreased over time. This significant decrease over time is thought to be due to the antithrombotic and infection treatment patients were receiving. We found a positive correlation between Ddimer and CRP levels of stroke cases in our study and the severity of SARS-CoV-2, and the majority of these cases were followed up under intensive care conditions with respiratory support. We were not able to find a relationship between NIHSS, which is used to identify the severity of stroke, and D-dimer and CRP levels. We predict one reason for this to be the regular and early administration of subcutaneous heparin in all SARS-CoV-2 cases with high D-dimer levels.

In Turkey and all around the world, rigorous and diligent efforts are being exerted to prevent death in SARS-CoV-2 cases. A patient presenting with cerebrovascular event findings during the pandemic should be suspected for SARS-CoV-2, a detailed medical history should be taken and the patient should be tested, if necessary. This is highly important both for diagnosing the disease early and for preventing the spread of the infection in the hospital and in the community. In our study, only 1 case presenting with stroke was tested after suspecting SARS-CoV-2 due to a routine thorax $\mathrm{CT}$, which then resulted in this case to be diagnosed early with SARS-CoV-2.

The most important limitation of our study was that etiological subtyping could not be done in stroke cases. Etiology could not be established in cases due to pandemic-related restrictions. The cases were only compared based on risk factors for stroke. Another limitation was that our results only cover moderate and severe SARS-CoV-2 cases requiring hospitalization.
Another limitation was that the association of medication used for SARS-CoV-2 with stroke cases could not be investigated. As we are facing with a new disease, medications used for treatment should also be investigated for cerebrovascular side effects.

\section{CONCLUSION}

It could be noted that our study is significant as it will contribute to the literature by providing information on cerebrovascular events observed in SARS-CoV-2 positive cases and will further improve experience on this issue. Our study supports the need for patients suffering from stroke, even if they are cryptogenic, regardless of the etiology of stroke, to be suspected of SARS-CoV-2 during the pandemic and for testing suspected cases.

Ethics Committee Approval: The study was approved by the Ethics Committee of Sakarya University Faculty of Medicine (27.07.2020, 437).

Conflict of Interest: None declared by the authors.

Financial Disclosure: None declared by the authors.

Acknowledgements: None declared by the authors.

\section{REFERENCES}

1. Wu Y, Xu X, Chen Z, Duan J, Hashimoto K, Yang L, et al. Nervous system involvement after infection with COVID-19 and other coronaviruses. Brain Behav Immun. 2020;87:18-22.

2. Jin H, Hong C, Chen S, Zhou Y, Wang Y, Mao L, et al. Consensus for prevention and management of coronavirus disease 2019 (COVID-19) for neurologists. Stroke Vasc Neurol. 2020;5(2):146-51.

3. Chen N, Zhou M, Dong X, Qu J, Gong F, Han Y, et al. Epidemiological and clinical characteristics of 99 cases of 2019 novel coronavirus pneumonia in Wuhan, China: a descriptive study. Lancet. 2020;395(10223):507-13.

4. Mao L, Jin H, Wang M, Hu Y, Chen S, He Q, et al. Neurological manifestations of hospitalized patients with coronavirus disease 2019 (COVID-19) in Wuhan, China. JAMA Neurol. 2020;77(6):683-90.

5. Aggarwal G, Lippi G, Michael Henry B. Cerebrovascular disease is associated with an increased disease severity in patients with coronavirus disease 2019 (SARS-COV-2): A pooled analysis of published literature. Int J Stroke. 2020;15(4):385-9.

6. Shahjouei S, Naderi S, Li J, Khan A, Chaudhary D, Farahmand G, et al. Risk of stroke in hospitalized SARS-CoV-2 infected patients: A multinational study. EBioMedicine. 2020;59:102939.

7. Li Y, Li M, Wang M, Zhou Y, Chang J, Xian Y, et al. Acute cerebrovascular disease following COVID-19: a single center, retrospective, observational study. Stroke Vasc Neurol. 2020;5(3):279-84.

8. Avula A, Nalleballe K, Narula N, Sapozhnikov S, Dandu V, Toom S, et al. COVID-19 presenting as stroke. Brain Behav Immun. 2020;87:115-9.

9. Siniscalchi A, Gallelli L. Could COVID-19 represent a negative prognostic factor in patients with stroke? Infect Control Hosp Epidemiol. 2020;41(9):1115-6.

10. Helms J, Tacquard C, Severac F, Leonard-Lorant I, 
Ohana $\mathrm{M}$, Delabranche $\mathrm{X}$, et al. High risk of thrombosis in patients with severe SARS-CoV-2 infection: a multicenter prospective cohort study. Intensive Care Med. 2020;46(6):1089-98.

11. Klok FA, Kruip MJHA, van der Meer NJM, Arbous MS, Gommers DAMPJ, Kant KM, et al. Incidence of thrombotic complications in critically ill ICU patients with COVID-19. Thromb Res. 2020;191:145-7.

12. Violi F, Pastori D, Cangemi R, Pignatelli P, Loffredo L. Hypercoagulation and antithrombotic treatment in coronavirus 2019: A new challenge. Thromb Haemost. 2020;120(6):949-56.

13. hsgm.saglik.gov.tr [Internet]. T.C. Sağlık Bakanlığ Halk Sağlığı Genel Müdürlüğü. COVID-19 (SARSCoV-2 Enfeksiyonu) Rehberi [Cited: 2020 August 25]. Available from: https://dosyamerkez.saglik.gov.tr/ Eklenti/37044,covid-19rehberipdf.pdf?0.

14. Wang D, Hu B, Hu C, Zhu F, Liu X, Zhang J, et al. Clinical characteristics of 138 hospitalized patients with 2019 novel coronavirus-infected pneumonia in Wuhan, China. JAMA. 2020;323(11):1061-9.

15. Guan WJ, Ni ZY, Hu Y, Liang WH, Ou CQ, He JX, et al. Clinical characteristics of coronavirus disease 2019 in China. N Engl J Med. 2020;382(18):1708-20.

16. AHA/ASA Stroke Council Leadership. Temporary emergency guidance to US stroke centers during the coronavirus disease 2019 (COVID-19) pandemic: On Behalf of the American Heart Association/American Stroke Association Stroke Council Leadership. Stroke. 2020;51(6):1910-2.

17. Li YC, Bai WZ, Hashikawa T. The neuroinvasive potential of SARS-CoV-2 may play a role in the respiratory failure of COVID-19 patients. J Med Virol. 2020;92(6):552-5.

18. Lodigiani C, Iapichino G, Carenzo L, Cecconi M, Ferrazzi P, Sebastian T, et al. Venous and arterial thromboembolic complications in COVID-19 patients admitted to an academic hospital in Milan, Italy. Thromb Res. 2020;191:9-14.

19. Wu Z, McGoogan JM. Characteristics of and important lessons from the coronavirus disease 2019 (COVID19) outbreak in China: summary of a report of 72314 cases from the Chinese Center for Disease Control and Prevention. JAMA 2020;323(13):1239-42.

20. Wu C, Chen X, Cai Y, Xia J, Zhou X, Xu S, et al. Risk factors associated with acute respiratory distress syndrome and death in patients with coronavirus disease 2019 pneumonia in Wuhan, China. JAMA Intern Med. 2020;180(7):934-43.

21. Goyal P, Choi JJ, Pinheiro LC, Schenck EJ, Chen R, Jabri A, et al. Clinical characteristics of COVID-19 in New York City. N Engl J Med. 2020;382(24):2372-4.

22. Tang N, Li D, Wang X, Sun Z. Abnormal coagulation parameters are associated with poor prognosis in patients with novel coronavirus pneumonia. J Thromb Haemost. 2020;18(4):844-7.

23. Khosravani H, Rajendram P, Notario L, Chapman MG, Menon BK. Protected code stroke: hyperacute stroke management during the coronavirus disease 2019 (COVID-19) pandemic. Stroke. 2020;51(6):1891-5.

24. Baracchini C, Pieroni A, Viaro F, Cianci V, Cattelan AM, Tiberio I, et al. Acute stroke management pathway during coronavirus-19 pandemic. Neurol Sci. 2020;41(5):1003-5. 